Ani Dwi Wimatsari, Sunarru Samsi Hariadi, Edhi Martono

Fakultas Pertanian, Universitas Gadjah Mada, Yogyakarta

*) Email korespondensi: anidwi94@gmail.com
AGRARIS: Journal of Agribusiness and Rural Develpoment Research

Vol. 5 No. 1 Januari-Juni 2019

\section{Sikap Pemuda Desa Terhadap Usahatani Salak Organik dan Pengaruhnya Terhadap Minat Berusahatani Salak Organik}

\section{Youth of Village Attitudes On Organic Farming of Snakefruit and It's Effect toward Their Interest on Farming Organic}

DOI: http://dx.doi.org/10.18196/agr.5175

\begin{abstract}
One of the problems that occur in agricultural sector is farmer regeneration. Farmer regeneration problem does not only occur in food crop sub-sector, but also in horticulture sub-sector. One of the commodities in horticultural sub-sector which also have this problem is salak. This study aims to determine the attitude of the young generation (village youth) toward salak organic farming along with its influencing factors, and to analyze the influence of village youth attitudes towards interest of village youth to continue salak organic farming. The study was conducted in Turi District, which is the center for salak production in Sleman Regency, with a total sample of 164 village youth taken by census technique. Data were analyzed using multiple linear regression and simple regression analysis. The results showed that role of new media and the role of agricultural extensionist had negative and significant effect on the attitudes of village youth, while the perceptions of village youth on organic salak farming and the role of parents had a positive effect on village youth attitudes towards labor factors in
\end{abstract}

farming. In addition, the attitude of village youth significantly affected the interest of village youth to continue organic salak farming.

Keywords: attitude, interest, organic salak farming, village youth

\section{INTISARI}

Salah satu permasalahan yang terjadi di sektor pertanian yaitu regenerasi petani. Masalah regenerasi petani tidak hanya terjadi di sub sektor tanaman pangan, namun juga sub sektor hortikultura. Salah satu komoditas dalam sub sektor hortikultura yang juga mengalami permasalahan ini yaitu salak. Penelitian ini bertujuan untuk mengetahui sikap generasi muda (pemuda desa) terhadap usahatani salak organik beserta faktor-faktor yang mempengaruhi, serta untuk menganalisis pengaruh sikap pemuda desa terhadap minat pemuda desa untuk melanjutkan usahatani salak organik. Penelitian dilakukan di Kecamatan Turi yang merupakan sentra produksi salak di Kabupaten Sleman, dengan total sampel penelitian yaitu 164 orang pemuda desa yang diambil dengan teknik sensus. Data dianalisis dengan menggunakan uji regresi linier berganda dan uji regresi sederhana. Hasil yang diperoleh yaitu bahwa peran media baru dan peran penyuluh pertanian lapangan berpengaruh negatif dan signifikan terhadap sikap pemuda desa, sedangkan persepsi pemuda desa terhadap usahatani salak organik dan peran orangtua berpengaruh positif terhadap sikap pemuda desa terhadap usahatani salak organik. Selain itu, sikap pemuda desa secara signifikan mempengaruhi minat pemuda desa untuk melanjutkan usahatani salak organik.

Kata kunci: minat, pemuda desa, sikap, usahatani salak organik

\section{PENDAHULUAN}

Permasalahan dalam sektor pertanian yang saat ini banyak dikaji oleh para ahli dan peneliti salah satu diantaranya yaitu regenerasi petani. Hal ini disebabkan karena saat ini sebagian besar petani di Indonesia tergolong dalam usia tua dan sedikit pemuda yang 
AGRARIS: Journal of Agribusiness

and Rural Development Research

berminat untuk melanjutkan bekerja di bidang pertanian (Wiyono, 2015). Setiawan (2012) menjelaskan bahwa umur petani menjadi salah satu faktor yang mempengaruhi keberlanjutan usahatani, sebab umur akan terkait erat dengan aktivitas petani dalam mengelola usahataninya, bahwa umur akan mempengaruhi daya psikologis, daya biologis, potensi dan tingkat kepekaan. Semakin tua umur petani, maka petani akan memiliki kemampuan fisik yang terbatas, sehingga keberlanjutan pengelolaan usahatani akan terhambat.

Isu regenerasi petani tidak hanya terjadi pada sub sektor tanaman pangan, namun juga pada sub sektor lainnya, salah satunya yaitu hortikultura. Weinberger dan Lumpik (dalam Lakitan 2014) menjabarkan bahwa hortikultura merupakan suatu bentuk diversifikasi usahatani yang berpotensi untuk mengurangi kemiskinan dan dapat membuka kesempatan kerja serta meningkatkan pendapatan petani. Salah satu komoditas unggulan hortikultura di Indonesia yaitu salak. Salak merupakan salah satu komoditas hortikultura yang saat ini mulai mendapat dukungan pemerintah untuk meningkatkan peluang ekspor ke negara-negara baru. Hal ini dibuktikan dengan baru-baru ini dilakukan penandatanganan kerja sama ekspor buah salak antara Indonesia dengan negara Selandia Baru (Julianto, 2017).

Upaya perluasan pasar penjualan buah salak menjadi potensi penjualan buah salak yang tidak hanya pada pasar lokal maupun nasional, namun juga pada pasar internasional. Akan tetapi, peluang ini dihadapkan pada permasalahan adakah generasi yang mau dan berminat untuk melanjutkan usahatani salak, sebab tanpa adanya generasi penerus, ketersediaan salak di masa mendatang akan terancam karena produksi buah salak akan terbatas. Oleh karena itu, penting untuk mengetahui bagaimana minat pemuda untuk melanjutkan usahatani salak organik di masa mendatang. Melalui kajian minat pemuda terhadap usahatani salak organik, akan dapat diketahui potensi keberlanjutan usahatani salak organik di masa yang akan datang.

Imelda, Rofi'i, \& Huwaida (2014) menjelaskan bahwa niat atau minat merupakan ukuran yang menunjukkan seberapa kuat kemauan seseorang untuk melakukan suatu tindakan. Engel menyatakan bahwa minat adalah fungsi dari keyakinan dan evaluasi mengenai sikap, serta dipengaruhi oleh keyakinan akan penilaian/pengharapan dari orang lain di lingkungan individu tersebut (norma subjektif) (Imelda, Rofi'i, \& Huwaida, 2014). Hal ini juga didukung oleh Marhaini (2008), yang menjelaskan mengenai hubungan antara sikap, minat dan norma subjektif pada Teori Tindakan Beralasan (Theory of Reasoned Action) oleh Ajzen dan Fishben.

Menurut teori sikap, keyakinan normatif dan dorongan untuk mengikuti pendapat orang lain terhadap suatu tindakan (norma subjektif), beserta sikap terhadap suatu tindakan akan menentukan minat seseorang dalam melakukan suatu tindakan. Secara garis besar, minat seseorang untuk melakukan suatu tindakan ditentukan oleh dorongan dari dalam diri, motif sosial, motif ekonomi dan faktor emosional (Crow dan Crow; Hurlock dalam Budiati, 2014). Selain faktor tersebut, beberapa faktor lain yang juga dapat mempengaruhi pembentukan minat dan keputusan pemuda untuk bekerja di bidang pertanian yaitu peran keluarga, akses terhadap informasi, (Tarigan, 2004; Lakitan, 2014; Ningsih dan Sjar, 2015) dan tingkat pendidikan (Wiyono, 2015; Hajrah, Siswoyo, \& Rahayu, 2016).

Orangtua/keluarga memegang peranan penting dalam pembentukan sikap terhadap pekerjaan di bidang pertanian, serta menentukan minat dan keputusan bagi pemuda desa untuk bekerja atau melanjutkan berusahatani, sebab orangtua/keluarga akan mempengaruhi pembentukan persepsi dan sikap pemuda terhadap pertanian (Nugraha, 2012). Terkait dengan pembentukan persepsi seseorang terhadap suatu objek/tindakan, penelitian Indraningsih (2011) menjelaskan bahwa akses terhadap media akan mempengaruhi pembentukan persepsi seseorang terhadap suatu objek. Hal ini didukung oleh Susilowati (2016), bahwa citra pertanian yang ditampilkan melalui media baru (media sosial/internet), akan menentukan persepsi pemuda terhadap usahatani. Terkait dengan pembentukan persepsi, Teori Persepsi oleh Umstot (1988) menjabarkan bahwa secara garis besar persepsi dapat dipengaruhi oleh orang yang memberi persepsi, objek yang dipersepsikan, dan situasi terjadinya 
persepsi. Informasi yang diperoleh individu tidak seluruhnya akan diproses dan diinterpretasikan, namun sebagian akan hilang atau ditolak dalam proses penyaringan. Melalui informasi yang diterima tersebut, individu akan menginterpretasikannya yang kemudian akan terbentuk persepsi. Berdasarkan persepsi yang terbentuk, akan mempengaruhi pembentukan sikap, perilaku dan perasaan terhadap objek yang dipersepsikan. Hal ini didukung oleh penelitian yang dilakukan oleh Limpo (2013), bahwa sikap positif siswa terhadap mata pelajaran matematika ditentukan oleh persepsi positif (baik) mereka terhadap lingkungan di sekolah.

Pembentukan sikap dan minat aktor di bidang pertanian tentu tidak terlepas dari peran penyuluh pertanian lapangan. Lionberger dan Gwin menjabarkan mengenai peran penyuluh, yaitu komunikator (pembawa/penyampai informasi atau inovasi), motivator, fasilitator proses, agen penghubung, guru yang mengajarkan dan membentuk keterampilan, pengelola program, pekerja kelompok, penjaga batas, promoter, konsultan, pembentuk lembaga, pemimpin lokal, work helper dan pekerja kelompok (Narso, Asngari, \& Muljono, 2012). Melalui optimalisasi peran-peran tersebut, yang didukung dengan metode, teknik dan sumberdaya yang memadai, diharapkan penyuluh akan mampu merubah sikap, persepsi dan perilaku aktor di bidang pertanian, tidak hanya petani namun juga pemuda desa, sehingga pemuda akan termotivasi, mampu dan mau untuk melanjutkan usahatani di masa mendatang.

Terkait dengan keberlanjutan pertanian, kajian tersebut tidak hanya difokuskan pada pengukuran sikap dan minat generasi muda untuk melanjutkan bekerja di bidang pertanian, namun juga pelaksanaan usahatani (budidaya) yang ramah lingkungan. Pengelolaan usahatani yang ramah lingkungan dapat dilakukan dengan melakukan budidaya tanaman secara organik. Kegiatan pertanian yang didasarkan atas perspektif ekologi (penggunaan sumberdaya alam alami yang efisien, meminimalkan penggunaan pestisida dan pupuk kimia), akan mendukung keberlanjutan pertanian di masa mendatang (Tumusiime dan Matotay, 2014). Oleh sebab itu, penelitian ini fokus dalam mengkaji minat pemuda desa dalam melakukan usahatani secara organik, hal ini dilakukan untuk mengetahui bagaimana potensi keberlanjutan pertanian tidak hanya dalam aspek sosial (minat), namun juga dalam aspek ekologis (lingkungan/alam). Secara garis besar, penelitian ini bertujuan untuk menganalisis sikap pemuda desa terhadap usahatani salak organik (sebagai representasi permasalahan regenerasi petani) dan bagaimana pengaruh sikap tersebut terhadap pembentukan minat pemuda desa untuk melanjutkan usahatani salak organik di masa yang akan datang.

\section{METODE PENELITIAN}

Penelitian dilakukan di Kecamatan Turi, Kabupaten Sleman, Daerah Istimewa Yogyakarta (DIY) pada tahun 2018. Kecamatan Turi dipilih sebagai lokasi penelitian karena daerah ini merupakan salah satu sentra produksi salak di Kabupaten Sleman dengan produksi tertinggi jika dibandingkan dengan kecamatan lain (Kecamatan Tempel dan Pakem) Sampel dalam penelitian ini adalah pemuda desa berusia 15-35 tahun yang mengusahakan/keluarga mereka memiliki kebun salak organik teregistrasi. Sampel penelitian sebanyak 164 orang, yang diambil dengan teknik sensus. Data diperoleh dengan teknik wawancara dan menggunakan kuesioner.

Pendekatan dasar dalam penelitian ini yaitu pendekatan kuantitatif, dimana data yang diperoleh dianalisis dengan uji regresi linier berganda untuk mengetahui faktor-faktor yang mempengaruhi sikap pemuda desa terhadap usahatani salak organik, dan uji regresi sederhana untuk menganalisis pengaruh sikap pemuda desa terhadap minat pemuda desa untuk melanjutkan usahatani salak organik di masa mendatang. Persamaan rumus regresi linier berganda yaitu (Sugiyono, 2014):

$$
\begin{aligned}
& Y 1=A+b_{1} X_{1}+b_{2} X_{2}+\ldots+b_{8} X_{8} . \\
& Y 2=A+b X_{Y 1} \ldots \ldots \ldots \ldots \ldots \ldots \ldots \ldots \ldots \ldots \ldots \ldots \ldots
\end{aligned}
$$

A merupakan konstanta, b adalah koefisien regresi, $\mathrm{X}$ adalah variabel independen. Pada persamaan 1), variabel independen yang diduga mempengaruhi sikap pemuda desa terhadap usahatani salak organik (Y1) yaitu jumlah pendidikan formal yang telah 
ditempuh oleh pemuda desa (X1), status keanggotaan pemuda desa dalam kelompok tani (X2), persepsi pemuda desa terhadap usahatani salak organik (X3), peran media baru (X4), peran penyuluh pertanian lapangan (X5), dan peran orangtua (X6). Setelah diketahui faktor-faktor yang mempengaruhi sikap pemuda desa terhadap usahatani salak organik, dilakukan analisis regresi sederhana untuk mengetahui pengaruh sikap tersebut (XY1) terhadap minat pemuda desa untuk melanjutkan usahatani salak organik (Y2), dengan persamaan 2) yaitu persamaan regresi sederhana. X1 memiliki satuan dalam tahun (data rasio), X2 merupakan dummy variabel, dimana kode 0 adalah 'tidak bergabung dalam kelompok tani' dan kode 1 adalah 'bergabung dalam kelompok tani', sedangkan X3, X4, X5, X6, XY1, dan Y2 merupakan data skala Likert (satuan skor).

Sebelum diuji menggunakan analisis regresi, dilakukan pengujian validitas dan reliabilitas kuesioner pada variabel sikap, persepsi, peran media baru, peran orangtua dan peran penyuluh pertanian lapangan. Pengujian (baik validitas-reliabilitas kuesioner dan regresi), dilakukan dengan SPSS 23. Kuesioner dinyatakan reliabel jika memiliki nilai Cronbach's Alpha Based on Standardized Item (CABSI) > 0,7. Apabila nilai CABSI semakin mendekati 1, maka konsistensi kuesioner dalam mengukur di setiap variabel akan semakin tinggi. Validitas kuesioner (kemampuan kuesioner/item pertanyaan di setiap variabel untuk mengukur apa yang seharusnya diukur) dinyatakan dengan nilai Corrected Item Total Correlation (CITC) > 0,1289 (dengan tingkat kesalahan $\alpha=10 \%$ ).

\section{HASIL DAN PEMBAHASAN SIKAP PEMUDA DESA TERHADAP USAHATANI SALAK ORGANIK}

Sikap dalam penelitian ini adalah respons pemuda desa, baik secara afektif (perasaan), kognitif (pengetahuan) maupun konatif (kecenderungan bertindak) terhadap usahatani salak organik. Respons (sikap) pemuda desa tersebut dapat bernilai positif (setuju) maupun negatif (tidak setuju). Secara garis besar, sebaran sikap pemuda desa terhadap usahatani salak organik di lokasi penelitian dijabarkan melalui Tabel 1.

TABEL 1. KATEGORI SIKAP PEMUDA DESA TERHADAP USAHATANI SALAK ORGANIK

\begin{tabular}{llcc}
\hline No. & Kategori Sikap & Jumlah (Orang) & Persentase (\%) \\
\hline 1. & Sangat Tidak Setuju & 0 & 0,00 \\
2. & Tidak Setuju & 3 & 1,83 \\
3. & Ragu-ragu & 39 & 23,78 \\
4. & Setuju & 105 & 64,02 \\
5. & Sangat Setuju & 17 & 10,37 \\
\hline & Jumlah & 164 & 100,00 \\
\hline
\end{tabular}

Berdasarkan Tabel 1., dapat diketahui bahwa sebagian besar pemuda desa memiliki penilaian yang setuju terhadap usahatani salak organik, yang ditunjukkan dengan persentase pemuda desa yang memiliki sikap setuju sebesar $64,02 \%$. Hal ini berarti bahwa pemuda desa setuju bahwa ketersediaan tenaga kerja dalam usahatani salak organik akan sangat menentukan keberlanjutan usahatani salak organik di masa mendatang. Pemuda desa beranggapan bahwa mereka (pemuda atau anak-anak petani salak) merupakan pihak yang berpotensi untuk dapat melanjutkan usahatani salak organik milik orangtua atau keluarga, sehingga mereka akan dapat berpartisipasi dalam upaya meregenerasi petani di usahatani salak organik. Selain setuju terhadap pentingnya ketersediaan tenaga kerja dalam usahatani salak organik, terkait dengan faktor tenaga kerja dalam hal manajemen usahatani salak organik, pemuda desa juga memiliki penilaian yang setuju. Hal ini berarti bahwa, selain ketersediaan jumlah, terkait dengan kualitas tenaga kerja dalam memanajemen usahatani salak organik, juga penting untuk dipertimbangkan, dengan kata lain pemuda desa menilai bahwa kecapakan/keterampilan tenaga kerja dalam usahatani salak sangat diperlukan untuk mendukung keberlanjutan usahatani salak di masa mendatang. Hal juga didukung melalui Tabel 2. tentang deskripsi tingkat sikap pemuda berdasarkan indikator dalam setiap komponen sikap, bahwa rata-rata sikap yang dimiliki pemuda desa terhadap aspek pentingnya kecakapan tenaga kerja, ketersediaan tenaga kerja serta kemudahan manajemen dalam usahatani salak organik 
TABEL 2. SIKAP PEMUDA DESA TERHADAP USAHATANI SALAK ORGANIK

\begin{tabular}{|c|c|c|c|c|}
\hline No. & Indikator & $\begin{array}{c}\text { Interval } \\
\text { Skor }\end{array}$ & $\begin{array}{l}\text { Skor } \\
\text { Rerata }\end{array}$ & $\begin{array}{l}\text { Tingkat } \\
\text { Sikap (\%) }\end{array}$ \\
\hline \multicolumn{5}{|c|}{ A. Kognitif (Pengetahuan) } \\
\hline 1. & $\begin{array}{l}\text { Kelangkaan tenaga kerja berakibat pada mundurnya penanaman, sehingga berpengaruh pada kualitas produk yang } \\
\text { dihasilkan. }\end{array}$ & $0-5$ & 2,72 & 54,39 \\
\hline 2. & $\begin{array}{l}\text { Kelangkaan tenaga kerja berakibat pada mundurnya penanaman, sehingga berpengaruh pada pertumbuhan tanaman } \\
\text { salak. }\end{array}$ & $0-4$ & 2,49 & 62,24 \\
\hline 3. & $\begin{array}{l}\text { Kelangkaan tenaga keria berakibat pada mundurnya penanaman, sehingga berpengaruh pada jumlah produksi salak } \\
\text { yang dihasilkan. }\end{array}$ & $0-4$ & 2,49 & 62,25 \\
\hline 4. & Tersedianya tenaga kerja dari dalam keluarga berperan dalam menjaga keberlaniutan usahatani salak organik. & $0-5$ & 3,89 & 77,77 \\
\hline 5. & Tersedianya tenaga kerja dari luar keluarga berperan dalam menjaga keberlanjutan usahatani salak organik. & $0-4$ & 2,73 & 68,22 \\
\hline 6. & $\begin{array}{l}\text { Tenaga keria berusia muda cenderung memiliki kemampuan dan kekuatan fisik yang lebih baik jika dibandingkan } \\
\text { dengan tenaga kerja yang tergolong tua. }\end{array}$ & $0-4$ & 2,73 & 68,28 \\
\hline 7. & $\begin{array}{l}\text { Tenaga keria berusia muda diperlukan dalam usahatani salak organik karena mereka mudah/cepat belajar mengenai } \\
\text { hal-hal baru (terutama terkait usahatani salak organik). }\end{array}$ & $0-4$ & 2,52 & 62,99 \\
\hline 8. & $\begin{array}{l}\text { Regenerasi petani dalam usahatani salak perlu dilakukan untuk mewujudkan keberlanjutan usahatani salak di masa } \\
\text { yang akan datang. }\end{array}$ & $0-4$ & 2,72 & 68,01 \\
\hline 9. & Informasi yang tepat mengenai usahatani salak organik dapat mengembangkan usahatani salak. & $0-5$ & 3,88 & 77,67 \\
\hline 10. & Dengan menggunakan bibit/benih organik akan dapat diperoleh produk salak yang berkualitas. & $0-6$ & 3,89 & 64,78 \\
\hline 11. & Dengan penggunaan bibit/benih organik akan dapat diperoleh produk salak yang bernilai jual tinggi. & $0-4$ & 2,72 & 68,12 \\
\hline \multirow[t]{3}{*}{12.} & Melalui pengolahan produk yang tepat, produk olahan salak akan dapat dipasarkan dengan peluang yang luas. & $0-4$ & 2,73 & 68,20 \\
\hline & $\begin{array}{lc} & \text { Jumlah (a) }\end{array}$ & $0-53$ & 35,51 & \\
\hline & Rata-rata (a) & & & 67,00 \\
\hline
\end{tabular}

\section{B. Afekif (Rasa Suka/Perasaan)}

1. Melakukan rehabilitasi jaringan irigasi karena mudah dilakukan.

2. Melakukan kegiatan penanaman di kebun karena tidak membutuhkan waktu yang cukup banyak.

$0-6 \quad 3,90 \quad 64,93$

3. Merawat tanaman salak di kebun agar terhindar dari gulma.

$0-4 \quad 2,34 \quad 58,46$

4. Merawat tanaman salak di kebun agar terhindar dari hama/hewan pengganggu sehingga hasil tetap terjaga.

5. Merawat tanaman salak di kebun agar terhindar dari penyakit sehingga hasil tetap terjaga.

$0-5 \quad 3,89 \quad 77,75$

6. Melakukan pemanenan sesuai waktu panen dan dengan cara yang tepat di kebun.

$\begin{array}{lll}0-5 & 3,89 & 77,77\end{array}$

7. Mencari informasi terkait usahatani salak organik untuk mengembangkan usahatani.

$\begin{array}{lll}0-4 & 2,72 \quad 68,09\end{array}$

7. Mencai informasi teckeit usahatanis

Jumlah (b)
Rata-rota (b)

$\begin{array}{lll}0-4 & 2,34 & 58,47\end{array}$

\begin{tabular}{|c|c|c|c|c|}
\hline \multicolumn{5}{|c|}{ C. Konatif (Kecenderungan Bertindak) } \\
\hline 1. & Mencari informasi terkait perkembangan iklim karena mudah diperoleh. & $0-4$ & 2,34 & 58,59 \\
\hline 2. & Melakukan rehabilitasi terhadap jaringan irigasi di kebun. & $0-4$ & 2,72 & 68,07 \\
\hline 3. & Melakukan kegiatan penanaman sesuai dengan masa tanam. & $0-4$ & 2,49 & 62,28 \\
\hline 4. & Melakukan perawatan dengan teknik yang tepat untuk menjaga hasil dalam usahatani salak. & $0-4$ & 2,72 & 68,11 \\
\hline 5. & Melakukan pemanenan sesuai dengan waktu panen karena akan mempengaruhi kualitas buah salak yang dipanen. & $0-4$ & 2,34 & 58,49 \\
\hline 6. & Melakukan rehabilitasi jaringan irigasi untuk menjaga ketersediaan air bagi budidaya salak di kebun. & $0-4$ & 2,34 & 58,53 \\
\hline \multirow[t]{5}{*}{7.} & Mencari informasi terkait usahatani salak organik karena dapat mengembangkan usahatani salak. & $0-4$ & 2,49 & 62,21 \\
\hline & Jumlah (c) & $0-28$ & 17,45 & \\
\hline & Rata-rota (c) & & & 62,33 \\
\hline & Jumlah $(a, b, c)$ & $0-113$ & 74,76 & \\
\hline & Rata-rata $(a, b, c)$ & & & 66,16 \\
\hline
\end{tabular}

Keterangan: Tingkat Sikap (dalam \%) 0-20=Sangat Tidak Setuju, 21-40=Tidak Setuju, 41-60=Ragu-ragu, 61-80=Setuju, 81-100=Sangat Setuju 
adalah setuju, yang ditunjukkan dengan nilai tingkat sikap sebesar 66,16\%. Melalui Tabel 2., juga dapat diketahui bahwa komponen sikap dengan nilai tertinggi yaitu pada komponen sikap afektif dengan rata-rata tingkat sikap sebesar 68,13\%. Hal ini menunjukkan bahwa pemuda desa setuju untuk senang dalam melakukan kegiatan manajemen dalam usahatani salak organik, terutama pada kegiatan perawatan tanaman salak di kebun agar terhindar dari penyakit dan serangan hama/OPT, sehingga kualitas dan kuantitas buah yang dihasilkan akan tetap terjaga. Indikator perawatan tanaman memiliki tingkat sikap tertinggi disebabkan karena sebagian pemuda desa membantu orangtua mereka untuk merawat tanaman salak di kebun milik keluarganya. Pemuda menganggap bahwa kegiatan perawatan tanaman ini mudah dilakukan sehingga mereka senang untuk melakukannya.

Melalui Tabel 2., juga dapat disimpulkan bahwa komponen sikap kognitif memiliki nilai tingkat sikap sebesar $67,00 \%$ yang berarti pemuda desa setuju bahwa ketersediaan tenaga kerja dari dalam keluarga berperan dalam menjaga keberlanjutan usahatani salak organik dan informasi yang tepat mengenai usahatani salak organik dapat mengembangkan usahatani salak organik. Hal ini berarti bahwa rata-rata pemuda desa memiliki evaluasi positif atau setuju tentang pentingnya regenerasi petani salak, yang salah satu upaya untuk mewujudkannya yaitu dengan mau meneruskan usahatani salak milik orangtua mereka. Selain itu, melalui kecakapan tenaga kerja pada usahatani salak organik dalam memperoleh informasi terkini dan terbaru terkait usahatani salak organik, akan dapat memajukan usahatani salak organik, atau dengan kata lain tenaga kerja yang secara aktif mencari informasi terbaru terkait usahatani salak organik akan dapat berpeluang mengembangkan usahatani salaknya. Pemuda desa dalam hal ini telah memahami akan pentingnya akses terhadap informasi dalam mendukung pengembangan usahatani salak organik.

Secara keseluruhan, indikator sikap yang memiliki nilai terendah yaitu pengetahuan bahwa kelangkaan tenaga kerja berakibat pada mundurnya penanaman, sehingga berpengaruh pada kualitas produk yang dihasilkan, dimana pemuda desa ragu- ragu akan hal tersebut. Hal ini disebabkan karena pemuda desa telah memahami mengenai berbagai faktor di luar tenaga kerja yang juga akan mempengaruhi keberhasilan usahatani salak organik, yaitu faktor modal dan alam-tanah. Hal ini didukung oleh Suratiyah (2006), bahwa faktor produksi dalam usahatani yaitu faktor alam, tanah; faktor tenaga kerjamanajemen; dan faktor modal, peralatan. Faktor manajemen melekat pada tenaga kerja karena aktor di bidang pertanian/petani berperan sebagai manajer dalam aktivitas usahatani, atau dengan kata lain seluruh kegiatan/aktivitas berusahatani sangat ditentukan oleh kecakapan dan kualitas tenaga kerja.

\section{FAKTOR-FAKTOR YANG MEMPENGARUHI SIKAP PEMUDA DESA TERHADAP USAHATANI SALAK ORGANIK}

Berdasarkan Tabel 2., dapat diketahui bahwa sikap pemuda desa terhadap usahatani salak organik dipengaruhi secara signifikan oleh faktor persepsi pemuda terhadap usahatani salak organik, peran media baru, peran penyuluh pertanian lapangan dan peran orangtua, sedangkan faktor pendidikan dan status keanggotaan tidak berpengaruh secara nyata. Secara bersama-sama, variabel-variabel independen tersebut signifikan mempengaruhi pembentukan sikap pemuda desa terhadap aspek tenaga kerja dalam usahatani salak organik sebesar 29,2\% dan sebanyak 70,8\% diantara dipengaruhi variabel-variabel lain di luar penelitian ini. Faktor pendidikan dan status keanggotaan pemuda desa dalam kelompok tani tidak berpengaruh terhadap pembentukan sikap pemuda desa terhadap aspek tenaga kerja dalam usahatani salak organik disebabkan karena berdasarkan observasi di lapangan, diperoleh data bahwa sebesar $80,49 \%$ pemuda desa di Kecamatan Turi menempuh pendidikan setingkat SMA. Selain itu, dari 164 orang responden, 85,98\% diantaranya tidak bergabung dalam kelompok tani. Hal ini membuktikan bahwa sebaran pemuda desa berdasarkan pendidikan dan status keanggotaan dalam kelompok tani memiliki kecenderungan bersifat homogen, sehingga tidak terdapat perbedaan yang nyata pada sikap mereka.

Faktor peran media baru dan peran penyuluh pertanian lapangan memiliki pengaruh signifikan negatif terhadap pembentukan sikap pemuda desa 
terhadap usahatani salak organik. Hal ini menandakan bahwa dengan semakin sering media baru berperan dalam menyediakan informasi mengenai usahatani salak organik, dan semakin sering peran penyuluh sebagai organisator, komunikator, motivator dan komunikator maka akan membuat sikap pemuda desa terhadap usahatani salak organik akan semakin negatif (kurang setuju).

\section{TABEL 3. HASIL ANALISIS REGRESI LINIER BERGANDA PADA FAKTOR- FAKTOR YANG MEMPENGARUHI SIKAP PEMUDA DESA TERHADAP USAHATANI SALAK ORGANIK}

\begin{tabular}{|c|c|c|c|c|c|}
\hline №. & Variabel & $\begin{array}{l}\text { Koefisien Regresi } \\
\text { (b) }\end{array}$ & † Hitung & Sig. & Keterangan \\
\hline 1. & Pendidikan & $-0,342$ & $-0,654$ & 0,514 & ns \\
\hline 2. & Status Keanggotaan & $-0,380$ & $-0,144$ & 0,885 & ns \\
\hline 3. & Persepsi & 0,493 & 3,885 & 0,000 & $* * *$ \\
\hline 4. & Peran Media Baru & $-0,121$ & $-2,216$ & 0,028 & $* *$ \\
\hline 5. & $\begin{array}{l}\text { Peran Penyuluh } \\
\text { Pertanian Lapangan }\end{array}$ & $-0,109$ & $-1,680$ & 0,095 & $*$ \\
\hline \multirow[t]{5}{*}{6.} & Peran Orangtua & 0,307 & 5,477 & 0,000 & $* * *$ \\
\hline & Konstanta & 52,380 & 6,836 & 0,000 & $* * *$ \\
\hline & Adjusted R square & 0,292 & & & \\
\hline & F hitung & 12,213 & & & \\
\hline & F tabel & 1,812 & & & \\
\hline
\end{tabular}

Jenis media baru yang banyak digunakan oleh pemuda desa yaitu media sosial dan internet/website, dengan tingkat peran media masing-masing sebesar $29,08 \%$ dan $25,02 \%$. Hal ini berarti bahwa pemuda desa jarang menggunakan media sosial dan internet/website untuk mencari informasi mengenai usahatani salak organik. namun, nilai tingkat penggunaan tersebut lebih besar jika dibandingkan dengan nilai tingkat intensitas penggunaan aplikasi elektronik pertanian, dimana nilai tingkat intensitas penggunaan media baru ini oleh pemuda desa hanya sebesar $10,72 \%$ atau dengan kata lain pemuda desa hampir tidak pernah menggunakan aplikasi elektronik pertanian. Pemuda desa lebih banyak menggunakan media sosial dan internet/website untuk mengakses informasi mengenai usahatani salak organik karena dianggap lebih mudah digunakan dan dekat dengan kehidupan mereka sehari-hari. Program aplikasi elektronik pertanian hampir tidak pernah digunakan oleh pemuda desa karena sampai saat ini, belum ada sosialisasi yang secara khusus memperkenalkan penggunaan media baru tersebut terutama untuk kalangan pemuda.

Peran media baru memiliki pengaruh negatif terhadap pembentukan sikap pemuda terhadap usahatani salak organik disebabkan karena informasi yang banyak disediakan melalui media baru terkait usahatani salak organik adalah fluktuasi harga jual produk salak. Informasi mengenai fluktuasi harga penjualan buah salak ini akan mempengaruhi penilaian pemuda desa terhadap usahatani salak organik, terutama dalam manajemen penjualan buah salak, dimana pemuda desa akan menilai bahwa harga jual buah salak kurang stabil sehingga menyebabkan pemasaran dan penjualan buah salak menjadi sulit dilakukan, terutama jika memasuki panen raya karena harga jual buah salak akan sangat rendah. Hal ini sesuai dengan Medium Theory oleh Marshall McLuhan, yang menjelaskan bahwa media, terlepas dari apapun isi yang disampaikan, akan berdampak pada diri individu dan masyarakat, dimana internet akan mempengaruhi masyarakat tanpa melihat situs apa yang diakses (Littlejohn dan Foss, 2011). Selain itu, Teori Kultivasi menjelaskan mengenai pengaruh media baru (yang merupakan salah satu bentuk terbaru media massa) terhadap pembentukan keyakinan dan sikap terhadap dunia sekitar. Azwar (2015) memaparkan bahwa media massa sebagai media informasi memiliki peranan penting sebagai sarana penyedia informasi dan hal tersebut membuat media massa memiliki pengaruh dalam membentuk opini dan kepercayaan seseorang. Hal ini disebabkan karena media massa akan memberikan kognitif baru bagi seseorang, dan kognitif tersebut yang akan mempengaruhi pembentukan sikap pada diri individu. Oleh sebab itu, apa yang disampaikan media baru mengenai usahatani salak organik akan mempengaruhi sikap pemuda desa terhadap usahatani salak organik.

Selain peran media baru, peran penyuluh pertanian lapangan juga memiliki pengaruh negatif terhadap pembentukan sikap pemuda desa terhadap usahatani salak organik. Hal ini disebabkan karena sebagian besar kelompok tani salak di Kecamatan Turi merupakan kelompok tani yang tergolong mandiri dan telah lama mengusahakan budidaya salak secara organik, sehingga mereka memiliki tingkat ketergantungan yang cukup rendah dengan penyuluh pertanian lapangan. Faktor selain peran media baru dan penyuluh pertanian lapangan yang juga secara signifikan mempengaruhi sikap pemuda desa terhadap usahatani salak organik yaitu faktor persepsi dan peran orangtua, dengan pengaruh positif. Hal ini berarti 
bahwa semakin sering peran orangtua dalam mendorong, memberikan informasi dan memfasilitasi pemuda desa dalam kegiatan usahatani salak organik, serta semakin baik interpretasi pemuda desa terhadap usahatani salak organik maka sikap pemuda desa terhadap usahatani salak organik akan semakin positif (setuju).

Menurut Umstot (1988), persepsi individu terhadap suatu objek akan mempengaruhi terbentuknya sikap, perilaku dan perasaan individu tersebut terhadap objek, atau dengan kata lain bahwa persepsi pemuda terhadap usahatani salak organik akan mempengaruhi sikap pemuda desa terhadap usahatani salak organik. Semakin baik persepsi dan interpretasi pemuda desa terhadap usahatani salak organik, maka pemuda desa akan cenderung memiliki sikap setuju terhadap usahatani salak organik, setuju bahwa usahatani salak organik mudah dilakukan baik dalam hal manajemen/perawatan hingga pemasaran. Terkait dengan peran orangtua, pemuda desa menilai orangtua memiliki peran penting dalam membentuk sikap mereka terhadap usahatani salak organik, sebab orangtua merupakan pihak yang paling dekat dengan mereka dalam lingkungan sosial terkecil, yaitu keluarga dan pihak yang akan mewariskan kebun salak kepada mereka. Orangtua banyak memberikan informasi mengenai usahatani salak organik, selain itu juga banyak melatih pemuda desa dalam praktik berusahatani salak organik karena sering mengajak pemuda desa untuk membantu merawat kebun salak milik keluarga. Hal ini sesuai dengan apa yang dikemukakan oleh Bandura dalam Baron (2004), bahwa sikap yang terbentuk dalam diri sesorang dapat terjadi karena orang tersebut mengimitasi tingkah laku orang lain dan banyak kasus yang menjelaskan bahwa seorang anak akan mengobservasi dan meniru apa yang orangtua mereka lakukan.

Penelitian ini, selain mengkaji mengenai sikap pemuda desa terhadap usahatani salak organik beserta faktor-faktor yang mempengaruhinya, juga mengkaji mengenai bagaimana pengaruh sikap tersebut terhadap pembentukan minat pemuda desa untuk melanjutkan usahatani salak organik di masa mendatang. Hal ini dilakukan untuk mengetahui bagaimana potensi keberlanjutan usahatani salak organik ditinjau dari ketersediaan tenaga kerja di masa yang akan datang.
TABEL 3. MINAT PEMUDA DESA DALAM USAHATANI SALAK ORGANIK

\begin{tabular}{|c|c|c|c|c|}
\hline No. & Indikator & $\begin{array}{l}\text { Interval } \\
\text { Skor }\end{array}$ & $\begin{array}{l}\text { Skor } \\
\text { Rerato }\end{array}$ & $\begin{array}{c}\text { Tingkat } \\
\text { Minat } \\
(\%)\end{array}$ \\
\hline 1. & $\begin{array}{l}\text { Minat untuk menggunakan benih/bibit organik unggul } \\
\text { bersertifikat yang diterapkan dalam usahatani salak di } \\
\text { masa yang akan datang. }\end{array}$ & $0-4$ & 2,23 & 55,65 \\
\hline 2. & $\begin{array}{l}\text { Minat untuk menggunakan pupuk organik dalam } \\
\text { usahatani salak di masa yang akan datang. } \\
\text { Minat untuk menggunakan air irigasi yang tidak }\end{array}$ & $0-4$ & 2,73 & 68,13 \\
\hline 3. & $\begin{array}{l}\text { terkontaminasi bahan kimia berbahaya dalam } \\
\text { usahatani salak di masa yang akan datang. } \\
\text { Minat untuk menggunakan pestisida yang ramah }\end{array}$ & $0-4$ & 2,23 & 55,78 \\
\hline 4. & $\begin{array}{l}\text { lingkungan dalam usahatani salak di masa yang akan } \\
\text { datang. }\end{array}$ & $0-4$ & 2,49 & 62,19 \\
\hline 5. & $\begin{array}{l}\text { Minat untuk selalu mencari informasi tentang } \\
\text { pertanian salak organik. }\end{array}$ & $0-4$ & 2,49 & 62,18 \\
\hline 6. & $\begin{array}{l}\text { Minat untuk selalu berpartisipasi dalam diskusi-diskusi } \\
\text { terkait usahatani salak di masa mendatang. } \\
\text { Minat untuk selalu berdiskusi tentang pentingnya }\end{array}$ & $0-4$ & 2,72 & 67,96 \\
\hline 7. & $\begin{array}{l}\text { pemakaian bahan organik dalam usahatani salak di } \\
\text { masa yang akan datang. } \\
\text { Minat untuk selalu berpartisipasi dalam pengambilan }\end{array}$ & $0-4$ & 2,72 & 68,12 \\
\hline 8. & $\begin{array}{l}\text { keputusan dalam usahatani salak di masa yang akan } \\
\text { datang. } \\
\text { Minat untuk menjalin kerjasama dengan teman }\end{array}$ & $0-4$ & 2,34 & 58,43 \\
\hline 9. & $\begin{array}{l}\text { sesama petani salak untuk menyukseskan usahatani } \\
\text { salak di masa mendatang. } \\
\text { Minat untuk menjalin kerjasama dengan tenaga }\end{array}$ & $0-4$ & 2,73 & 68,14 \\
\hline 10. & $\begin{array}{l}\text { pendamping/penyuluh untuk menyukseskan } \\
\text { usahatani di masa mendatang. }\end{array}$ & $0-4$ & 2,49 & 62,20 \\
\hline 11. & $\begin{array}{l}\text { Minat untuk menjalin kerjasama dengan } \\
\text { lembaga/instansi/dinas untuk menyukseskan } \\
\text { usahatani di masa mendatang. }\end{array}$ & $0-5$ & 3,89 & 77,71 \\
\hline 12. & $\begin{array}{l}\text { Minat untuk menjalin kerjasama dengan perguruan } \\
\text { tinggi pertanian untuk menyukseskan usahatani di } \\
\text { masa mendatang. } \\
\text { Minat untuk melanjutkan usahatani salak organik }\end{array}$ & $0-4$ & 2,49 & 62,23 \\
\hline 13. & $\begin{array}{l}\text { untuk mewujudkan ketersediaan tenaga kerja di } \\
\text { bidang pertanian salak di masa yang akan datang. }\end{array}$ & $0-5$ & 3,89 & 77,72 \\
\hline 14. & $\begin{array}{l}\text { Minat untuk menambah keterampilan agar usahatani } \\
\text { dapat semakin berkembang. }\end{array}$ & $0-4$ & 2,49 & 62,18 \\
\hline 15. & $\begin{array}{l}\text { Minat untuk menambah pengetahuan agar usahatani } \\
\text { dapat semakin berkembang. } \\
\text { Minat untuk tetap mempertahankan lahan budidaya }\end{array}$ & $0-5$ & 3,88 & 77,70 \\
\hline \multirow[t]{3}{*}{16.} & $\begin{array}{l}\text { salak saat ini untuk tetap digunakan sebagai lahan } \\
\text { budidaya salak di masa yang akan datang. }\end{array}$ & $0-4$ & 2,48 & 62,09 \\
\hline & Jumlah & $0-67$ & 44,27 & \\
\hline & Rata-rato & & & 66,07 \\
\hline
\end{tabular}

Keterangan: Tingkat Minat (dalam \%) 0-20=Sangat Tidak Berminat, 21-40=Tidak Berminat, $41-60=$ Ragu-ragu, $61-80=$ Berminat, $81-100=$ Sangat Berminat

\section{MINAT PEMUDA DESA UNTUK MELANJUTKAN USAHATANI SALAK ORGANIK}

Berdasarkan Tabel 3., dapat diketahui bahwa secara keseluruhan, rata-rata tingkat minat pemuda desa untuk melanjutkan usahatani salak organik di masa mendatang yaitu sebesar $66,07 \%$ atau pemuda 
desa berminat untuk melanjutkan usahatani salak organik. Pemuda desa berminat melanjutkan usahatani salak organik terutama disebabkan karena mereka memahami bahwa dengan ikut serta dalam melanjutkan usahatani salak organik, mereka akan berkontribusi dalam meuwujudkan ketersediaan tenaga kerja dalam usahatani salak organik dan mendukung terwujudnya keberlanjutan usahatani salak di masa yang akan datang.Pemuda desa memiliki minat yang paling tinggi dalam hal menjalin kerjasama dengan lembaga/instansi/dinas untuk menyukseskan usahatani di masa mendatang. Hal ini disebabkan karena dengan menjalin kerjasama dengan berbagai pihak yang terkait dengan usahatani salak organik sebagai upaya untuk mengembangkan usahatani salak organik di masa depan. Selain itu, pemuda desa juga memiliki minat yang tinggi untuk menambah pengetahuan tentang usahatani salak organik. Hal ini karena pemuda memahami akan pentingnya pengetahuan dasar yang cukup mengenai manajemen dan pelaksanaan usahatani salak organik, sebab dengan berbagai informasi yang tepat mengenai usahatani salak organik, mereka akan melaksanakan usahatani salak organik dengan baik, sehingga kuantitas dan kualitas produksi salak akan terjamin. Melalui terjaminnya kualitas dan kuantitas produksi, maka pemasaran/penjualan dan harga jual produk akan semakin baik, sehingga akan berdampak pada semakin banyaknya peluang peningkatan keuntungan dan pendapatan.

Aspek yang memiliki tingkat minat paling rendah yaitu minat pemuda desa untuk menggunakan benih/bibit organik unggul bersertifikat yang diterapkan dalam usahatani salak di masa yang akan datang. Hal ini disebabkan karena sebagian besar tanaman salak yang ada di kebun mereka/di kebun milik keluarga mereka merupakan tanaman yang sudah berasal turun-temurun dari orangtua mereka. Saat ini, mereka menganggap tanaman tersebut masih dalam kualitas yang baik untuk memproduksi buah salak, sehingga mereka belum berminat untuk mengganti tanaman salak mereka dengan tanaman salak yang baru. Penggantian tanaman salak dengan tanaman baru hanya dilakukan pada sebagian sedikit tanaman di kebun yang mati/rusak karena faktor alam (bencana alam) dan serangan OPT (organisme pengganggu tanaman)/penyakit, sehingga mereka belum pernah melakukan pembongkaran lahan secara keseluruhan. Selain itu, sebagian besar petani di Kecamatan Turi melakukan cangkok untuk memperoleh tanaman salak yang berkualitas, dan cangkok tersebut dilakukan pada tanaman yang mereka miliki sendiri. Oleh karena itu, mereka tidak terlalu berminat untuk mencari benih/bibit salak lain sebab kualitas tanaman yang mereka miliki sudah tergolong baik.

Melalui Tabel 3., dapat diketahui bahwa tidak ada pemuda desa yang memiliki minat sangat kuat (sangat berminat) untuk melanjutkan usahatani salak organik di masa mendatang. Hal ini disebabkan karena sebagian besar pemuda desa berminat melanjutkan usahatani salak disebabkan karena mereka ingin meneruskan pengelolaan kebun salak dari orangtua mereka, selain itu mereka juga ingin melanjutkan usahatani salak organik (bekerja di bidang usahatani salak organik) sebagai pekerjaan sampingan. Hal ini berarti rata-rata pemuda desa ingin memiliki pekerjaan utama di luar sektor usahatani salak organik, dan berminat untuk mengembangkan usahatani salak organik melalui pekerjaan sampingan.

\section{PENGARUH SIKAP PEMUDA DESA TERHADAP USAHATANI SALAK ORGANIK PADA PEMBENTUKAN MINAT UNTUK MELANJUTKAN USAHATANI SALAK ORGANIK}

Berdasarkan analisi, dapat diketahui bahwa terdapat pengaruh sikap pemuda desa pada usahatani salak organik terhadap pembentukan minat pemuda desa untuk melanjutkan usahatani salak organik di masa yang akan datang. Hal ini berarti bahwa semakin setuju penilaian pemuda desa terhadap ketersediaan tenaga kerja, kualitas tenaga kerja dan manajemen dalam usahatani salak organik, maka minat pemuda desa untuk melanjutkan usahatani salak organik akan semakin tinggi. Secara jelas, hasil analisis regresi sederhana pengaruh sikap pemuda desa terhadap minat melanjutkan usahatani salak organik dijabarkan dalam Tabel 4. 
TABEL 4. PENGARUH SIKAP PEMUDA DESA TERHADAP MINAT MELANJUTKAN USAHATANI SALAK ORGANIK

\begin{tabular}{lccc}
\hline \multicolumn{1}{c}{ Variabel } & $\begin{array}{c}\text { Koefisien } \\
\text { Regresi (b) }\end{array}$ & † Hitung & Sig. \\
\hline Minat & 0,494 & $9,784^{* * *}$ & 0,000 \\
Konstanta & 7,303 & $1,904^{*}$ & 0,059 \\
\hline Adjusted R square & 0,368 & \\
F hitung & $95,728^{* * *}$ \\
\hline \multicolumn{4}{l}{ Keterangan: ${ }^{* * *},{ }^{* *},{ }^{*}$, ns berturut-turut yaitu signifikan pada alfa 1\%, 5\%, } \\
& $10 \%$ serta tidak signifikan
\end{tabular}

Terkait dengan pengaruh sikap pemuda desa pada usahatani salak organik terhadap minat pemuda dalam melanjutkan usahatani salak organik, dapat diketahui melalui Tabel 4. Berdasarkan Tabel 4., dapat disimpulkan bahwa terdapat pengaruh signifikan yang positif antara sikap pemuda desa terhadap minat pemuda desa untuk melanjutkan usahatani salak organik. Hal ini berarti bahwa semakin positif (baik/setuju) sikap pemuda desa pada usahatani salak organik, maka mereka akan semakin berminat untuk melanjutkan usahatani salak organik. Semakin baik/setuju sikap pemuda desa terhadap kemudahan manajemen/pelaksanaan kegiatan budidaya salak dan pemasaran/penjualan salak, maka pemuda akan semakin berminat untuk melanjutkan usahatani salak organik. Selain itu, dengan semakin pahamnya pemuda desa tentang pentingnya regenerasi petani dan peran mereka dalam mendukung terwujudnya keberlanjutan usahatani salak organik, maka mereka akan semakin berminat untuk melanjutkan usahatani salak organik di masa yang akan datang.

Hubungan sikap pemuda desa pada usahatani salak organik dengan minat untuk melanjutkan berusahatani salak organik secara jelas dijabarkan melalui Gambar 1. Melalui Gambar 1., dapat diketahui bahwa melalui kenaikan satu satuan sikap pemuda desa maka akan terjadi kenaikan minat pemuda desa untuk melanjutkan usahatani salak organik sebesar 7,303 satuan skor. Selain itu, berdasarkan Tabel 4., juga dapat disimpulkan bahwa sebesar 36,8\% minat pemuda desa dalam melanjutkan usahatani salak organik ditentukan oleh sikap mereka terhadap usahatani salak organik (terutama pada faktor ketersediaan dan keterampilan serta manajemen dalam usahatani salak organik), dan sebesar 63,2\% dipengaruhi oleh variabel lain di luar penelitian ini.

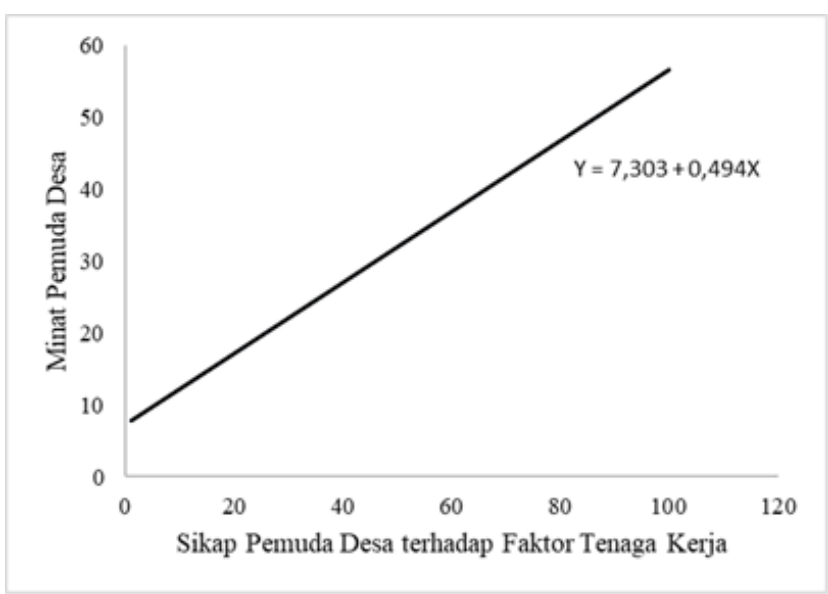

\section{GAMBAR 1. SIKAP PEMUDA DESA PADA USAHATANI SALAK ORGANIK TERHADAP MINAT MELANJUTKAN USAHATANI SALAK ORGANIK}

\section{KESIMPULAN}

Faktor-faktor yang mempengaruhi sikap pemuda desa terhadap usahatani salak organik yaitu peran orangtua, peran penyuluh pertanian lapangan, peran media baru, dan persepsi pemuda desa terhadap usahatani salak organik. Persepsi pemuda desa terhadap usahatani salak organik dan peran orangtua memiliki pengaruh positif terhadap pembentukan sikap pemuda desa, sedangkan peran penyuluh pertanian dan peran media baru berpengaruh negatif dalam membentuk sikap pemuda desa terhadap usahatani salak organik. Selain itu, dapat disimpulkan bahwa terdapat pengaruh positif yang signifikan antara sikap pemuda desa terhadap usahatani salak organik dengan pembentukan minat pemuda desa untuk meneruskan usahatani salak organik.

Peningkatan minat pemuda desa untuk melanjutkan usahatani salak organik dapat dilakukan dengan memperbaiki persepsi pemuda desa terhadap usahatani salak organik. Selain itu, juga dapat dengan mengoptimalkan penyebaran informasi positif mengenai usahatani salak organik melalui media baru, terutama melalui media sosial dan internet/website. Melalui penyebaran informasi mengenai usahatani salak organik yang positif (misalnya informasi mengenai cerita sukses petani salak, kebijakan baru terkait komoditas salak, peluang dan potensi pengembangan pasar penjualan salak dalam skala lokal, 
nasional maupun internasional), akan dapat memperbaiki penilaian pemuda desa terhadap usahatani salak organik. Apabila interpretasi, penilaian dan sikap pemuda desa terhadap usahatani salak organik akan semakin baik, maka potensi peningkatan minat pemuda desa untuk melanjutkan usahatani salak organik juga akan semakin meningkat.

\section{DAFTAR PUSTAKA}

Azwar, S. (2015). Sikap Manusia: Teori dan Pengukurannya. Yogyakarta: Pustaka Pelajar.

Baron, R. A. dan Byrne, D. (2004). Psikologi Sosial, Jilid Satu Edisi Kesepuluh (diterjemahkan dari Social Psychology, 10th Edition oleh $R$. Djuwita). Jakarta: Erlangga.

Budiati, I. (2014). Implikasi minat siswa dalam pengelolaan pertanian terhadap keberlanjutan minat bertani di wilayah Kecamatan Parongpong. Jurnal Pendidikan IImu Sosial 23 (2) (pp. 103-107).

Hajrah, Siswoyo, B. B., and Rahayu, W. P. (2016). Effect of entrepreneurial education and economic condition of parents towards an entrepreneurship attitudes through the entrepreneurship interest. IOSR Journal of Business and Management 18 (6) (pp. 105110).

Imelda, S., Rofi'i, dan Huwaida, H. (2014). Pengaruh sikap dan norma subyektif terhadap minat konsumen (studi pada pengguna refill tinta printer Dataprint di Banjarmasin). Study and Management Research 11 (2) (pp. 39-51).

Indraningsih, K. S. (2011). Pengaruh penyuluhan terhadap keputusan petani dalam adopsi inovasi teknologi usahatani terpadu. Jurnal Agro Ekonomi 29 (1) (pp. 1-24).

Julianto, P. A. (2017). Salak Pondoh Asal Sleman Tembus Pasar Selandia Baru. Kumparan. Retrieved from https://kumparan .com/wijinurhayat/salak-ri-mulai-diekspor-ke-selandiabaru-tahun-ini

Lakitan, B. (2014). Identifikasi teknologi yang relevan untuk mendukung diversifikasi usaha petani dan diversifikasi konsumsi pangan di Indonesia. Jurnal Teknovasi Indonesia 3(1) (pp. 1-25).

Limpo, J. N., Oetomo, H., dan Suprapto, M. H. (2013). Pengaruh lingkungan kelas terhadap sikap siswa untuk pelajaran matematika. Humanitas 10 (1) (pp. 37-48).
Littlejohn, S. W. dan Foss, K. A. (2011). Teori Komunikasi (Diterjemahkan dari Theories of Human Communication).Jakarta: Salemba Humanika.

Marhaini. (2008). Analisis perilaku konsumen dalam pembelian komputer merek Acer (studi kasus: mahasiswa fakultas ekonomi Universitas Sumatera Utara). Jurnal Manajemen Bisnis 1 (3) (pp. 89-96).

Narso, A. S., Asngari, P. S., dan Muljono, P. (2012). Strategi pengembangan peran penyuluh pertanian lapang di Provinsi Banten. Jurnal Penyuluhan 8 (2) (hal. 176-183).

Ningsih, F. dan Sjar, S. (2015). Faktor-faktor yang menentukan keterlibatan pemuda pedesaan pada kegiatan pertanian berkelanjutan. Jurnal Penyuluhan 11 (1) (pp. 23-37).

Nugraha, Y. A. (2012). Hubungan Orang Tua, Media Massa, dan Teman dengan Sikap Pemuda Terhadap Pekerjaan di Bidang Pertanian. Tesis: Sekolah Pascasarjana Institut Pertanian Bogor.

Setiawan, I. (2012). Agribisnis Kreatif: Pilar Wirausaha Masa Depan, Kekuatan Dunia Baru Menuju Kemakmuran Hijau. Jakarta: Penebar Swadaya.

Suratiyah, K. (2006). I/mu Usahatani, Cetakan I. Jakarta: Penebar Swadaya.

Susilowati, S. H. (2016). Fenomena penuaan petani dan berkurangnya tenaga kerja muda serta implikasinya bagi kebijakan pembangunan pertanian. Forum Penelitian Agro Ekonomi 34 (1) (pp. 35-55).

Tarigan, H. (2004). Representasi pemuda pedesaan mengenai pekerjaan pertanian: kasus pada komunitas perkebunan teh rakyat di Jawa Barat. ICASERD Working Paper No.29. Pusat Penelitian dan Pengembangan Sosial Ekonomi Pertanian, Badan Penelitian dan Pengembangan Pertanian, Departemen Pertanian, Bogor.

Tumusiime, E. and Matotay, E. (2014). Agriculture sustainability, inclusive growth, and development assistance: insights from Tanzania. Journal of Sustainable Development 7 (4) (pp. 181-190).

Umstot, D. D. (1987). Understanding Organizational Behavior. St. Paul: West Publishing Company.

Wiyono, S. (2015). Kajian Regenerasi Petani: Pada Keluarga Petani Padi dan Hortikultura November 2015. Bogor: Koalisi Rakyat untuk Kedaulatan Pangan (KRKP). 